\title{
Reports of the Nondelegation Doctrine's Death Are Greatly Exaggerated
}

\author{
Larry Alexander $\dagger$ \\ Saikrishna Prakash††
}

The nondelegation doctrine has roots that extend as far back as three centuries, or so most of us suppose. In The Second Treatise of Government, John Locke listed four constraints on the legislative power, the last that the power,

being derived from the People by a positive voluntary Grant and Institution, can be no other, than what that positive Grant conveyed, which being only to make Laws, and not to make Legislators, the Legislative can have no power to transfer their Authority of making Laws, and place it in other hands.'

Most contemporary readers have assumed two things about Locke's statement: First, that the legislative power was the power to make rules for society. Second, that this delegated power to make laws could not be transferred to third parties because the people had never authorized their agents to further delegate. These two principles underlay the conventional nondelegation doctrine, which maintains that if a statutory delegation of discretion to third parties sweeps too broadly, it will constitute an impermissible delegation of legislative power.

In their recent article, Interring the Nondelegation Doctrine, Professors Eric Posner and Adrian Vermeule reconsider the meaning of Locke's epigram and reassess the foundations of the nondelegation doctrine. In their view, the "legislative power" generally references the right to vote on bills in a legislature along with the other de jure powers of legislators. Moreover, Locke's maxim means no more than that the legislature cannot make third parties "legislators" by giving them the power to vote in the legislature. So when Article I of the Constitution speaks of "legislative Powers," it refers to those powers

$\dagger \quad$ Warren Distinguished Professor of Law, University of San Diego School of Law.

$\dagger \dagger$ Professor of Law, University of San Diego School of Law. We would like to thank Laurence Claus, Vasan Kesavan, Gary Lawson, and Michael Rappaport for their helpful comments.

1 John Locke, The Second Treatise of Government, in Two Treatises of Government 265, $\S 141$ at 363 (Cambridge 1988) (Peter Laslett, ed).

2 Eric A. Posner and Adrian Vermeule, Interring the Nondelegation Doctrine, $69 \mathrm{U}$ Chi L Rev 1721 (2002).

3 US Const Art I, $\$ 1$ ("All legislative Powers herein granted shall be vested in a Congress of the United States, which shall consist of a Senate and House of Representatives."). 
individually held by federal legislators, including most prominently the right to vote on bills. Furthermore, under their "naïve" nondelegation doctrine, these are the legislative powers that cannot be delegated to third parties. Under their view, neither Locke's epigram nor the federal Constitution goes further and prohibits broad delegations of discretion to third parties because such delegations do not create legislators and hence cannot delegate legislative power. Accordingly, should Congress delegate to some third party its entire power to "regulate Commerce," Congress has not delegated legislative power at all in either a Lockean or a constitutional sense.

Professors Posner and Vermeule deserve praise for reexamining fundamental assumptions about the nature and meaning of legislative power and of the nondelegation doctrine. When scholars do not periodically reconsider conventional wisdom, scholarship stagnates and shibboleths are unreflectively accepted as constitutional gospel.

Having said this, we doubt that they truly have laid to rest either the traditional understanding of legislative power or the conventional nondelegation doctrine. Our disagreements are both normative and descriptive. We cannot discern (and they do not advance) a plausible rationale for simultaneously permitting Congress to delegate large amounts of lawmaking or rulemaking discretion to third parties while strictly forbidding delegations of the right to vote in Congress.' Moreover, as an original matter, we believe that Locke and the Constitution used the phrase "the legislative power" to refer to the power to make rules for society and not the ability to exercise the de jure powers of legislators. Hence, if one concludes that Congress cannot delegate legislative powers (either because such grants are not authorized or, alternatively, are implicitly forbidden), one must be worried that at some point, the delegation of large amounts of discretion might constitute a delegation of legislative power.

Furthermore, whatever meaning one should ascribe to the phrase "legislative Powers" found in the Article I Vesting Clause, we think that Posner and Vermeule too quickly reject the conventional reading of Locke's nondelegation principle. Their revisionist reading simply cannot make sense of Locke's repeated claims that only those whom the people have appointed as legislators can make rules for the people.

\footnotetext{
4 US Const Art I, $\$ 8, \mathrm{cl} 3$ (“[The Congress shall have Power] To regulate Commerce with foreign Nations, and among the several States, and with the Indian Tribes.").

5 Just to be clear, we are not arguing that Congress (or its members) may delegate the right to vote; we are only suggesting that this prohibition, in the absence of the conventional nondelegation doctrine, seems pointless. Either both delegations of votes and delegations of excessive discretion are unconstitutional, or both are permitted. The naïve view, by permitting one (extreme delegations of discretion) and not the other (delegations of the vote), strikes us as the least plausible account.
} 
Locke denied that the legislative power entailed the power to make third parties into legislators by delegating to them the right to make laws. He was not merely claiming that those with the legislative power could not cede votes in the legislature.

Finally, we conclude that if Posner and Vermeule applied the relentless criticism that they visit upon the conventional nondelegation doctrine to the naïve prohibition on the delegation of legislative voting rights, the naïve prohibition would seem equally dead. The "heavy burden" that they insist applies to the conventional nondelegation doctrine makes all implicit constraints extremely dubious. Perhaps we should prepare for two interments rather than one.

Although we have sympathy for the conventional nondelegation doctrine, space considerations prevent us from mounting an adequate defense of it here. Hence, all we claim is that if one concludes that the delegation of legislative power is impermissible (for whatever reason), one must have in mind a prohibition akin to the conventional nondelegation doctrine. If, as Posner and Vermeule claim and as many others believe, the Constitution prohibits the delegation of legislative power, the nondelegation doctrine is alive and kicking.

\section{WHY WOULD THE FOUNDERS ADOPT THE NAÏVE VIEW? THE NORMATIVE CRITIQUE}

Posner and Vermeule's naïve view of the nondelegation doctrine-that neither Congress nor its members may delegate votes in Congress but may delegate unbridled discretion to implement policy through rules and regulations - naturally raises the normative question of what reasons the Founders might have had for adopting it. Although the basic question both for Posner and Vermeule and for us is whether the Founders constitutionalized the naïve view, the normative considerations for and against that view have the status of evidence. If the naïve view lacks both a plausible normative rationale and a textual warrant, that is pretty strong evidence that the Founders never endorsed the naïve view. As discussed below, we are unaware of any sound reasons for enacting the naïve view's partial prohibition on delegations.

6 For a defense of the conventional nondelegation doctrine, see generally Gary Lawson, Delegation and Original Meaning, 88 Va L Rev 327 (2002). For an attempt to make sense of the many seeming exceptions to the nondelegation doctrine, see Michael B. Rappaport, The Selective Nondelegation Doctrine and the Line Item Veto: A New Approach to the Nondelegation Doctrine and Its Implications for Clinton v. City of New York, 76 Tulane L Rev 265, 345-55 (2001). For discussions of the conventional nondelegation doctrine's implications for statutory interpretation, see John F. Manning, The Nondelegation Doctrine as a Canon of Avoidance, $2000 \mathrm{~S}$ Ct Rev 223, 228; Cass R. Sunstein, Nondelegation Canons, 67 U Chi L Rev 315, 321-22 (2000). 
A. Giving a Vote in Congress to the Secretary of Commerce

On Posner and Vermeule's naïve view, the Constitution forbids Congress (or individual members) from giving a vote in Congress to the Secretary of Commerce (or anyone else not elected to Congress). That, for them, is the beginning and the end of the nondelegation doctrine. On the other hand, on their view, Congress may statutorily delegate all of its authority over commercial affairs to the Secretary of Commerce. The latter would be functionally equivalent to giving the Secretary of Commerce 218 (of 435) votes in the House and 51 (of 100) votes in the Senate.'

We see no good reason at all for supposing that the Founders (or anyone else) would forbid Congress from giving the Secretary a single vote but authorize the grant to the Secretary of the equivalent of a majority of the votes. Nothing is gained by authorizing one form of delegation and barring the other because in both situations, individuals not part of Congress enact laws.

Now Posner and Vermeule might say that giving a vote in Congress to the Secretary is different from giving the Secretary Congress's policy discretion in this respect: When Congress votes to retract the latter, the Secretary cannot vote, whereas if he has been validly given a vote in Congress, he may vote on its retraction. But, of course, Congress could specify that the Secretary could not vote on bills that would retract his authority. Moreover, the distinction overlooks the difficulty - which the Founders would certainly have foreseen - of retracting policy discretion granted to the executive branch. The latter requires either that the President consent to the retraction-which is quite unlikely - or that Congress muster supermajorities in favor of the retraction in both chambers. Because the President will be much more resistant to losing vast amounts of policy discretion than to losing one vote of 535, delegations of the former type are more problematic. Yet the naïve view permits such delegations and only prohibits the far less significant delegation.

B. The Naïve View Undermines Numerous Constitutional Processes and Provisions

Though Posner and Vermeule do not supply a normative rationale for accepting their naive view of delegation, they do advance a structural inference meant to support their narrow, naive prohibition of legislative voting rights. The Constitution, they say, sets out a detailed process for selecting members of Congress. This process, and

7 If one disregards the President's ability to fire the Secretary, the delegation would consist of two-thirds of the votes in each chamber, enough to override a presidential veto. 
only this process, determines who the members of Congress are. And only they can vote in Congress. ${ }^{8}$ Hence, there is an impermissible delegation if and only if the detailed selection process is circumvented and someone else is given one or more de jure powers of federal legislators.

Yet we take that detailed selection process to imply a broader conclusion. We see little reason for specifying a detailed selection process if those selected may transfer the substance of their legislative discretion to persons who are not selected by that process. Legislative voting is but the means by which congressional powers found in Article I, Section 8 are exercised. If others likewise may exercise those legislative powers, that too would obviate the detailed selection process for legislators.

Indeed, the naïve view not only undercuts the Constitution's detailed process for selecting legislators, it also undermines numerous constitutional features. Consider bicameralism: That feature is designed to promote certain values (deliberation, increasing small state influence, a supermajority consensus, etc.). Yet if Congress can transfer all substantive policy discretion to the executive, these values are disserved. The values may affect the delegations that Congress passes, but they will not affect the laws created outside of Congress in the same way.

Similarly, consider the Incompatibility Clause, which prevents members of Congress from simultaneously holding positions in the executive branch. ${ }^{9}$ Whatever types of self-aggrandizement or corruption the Clause is meant to prevent are surely much more likely to occur if Congress delegates its power to make law to the executive. Indeed the problem is exacerbated because then one entity makes and executes the law.

Finally, consider the Emoluments Clause, which prevents members of the executive branch from getting the benefit of pay increases that they may have previously voted upon in Congress." If that form of self-dealing worried the Framers sufficiently to result in their enacting a specific constitutional prohibition, they would have worried much more about the self-dealing that could occur in a world where the Congress could allow the President to set the salaries of the entire executive branch.

\footnotetext{
8 See Posner and Vermeule, 69 U Chi L Rev at 1726 (cited in note 2).

9 US Const Art I, $\$ 6, \mathrm{cl} 2$ ("[N]o Person holding any Office under the United States, shall be a Member of either House during his Continuance in Office.").

10 Id ("No Senator or Representative shall, during the Time for which he was elected, be appointed to any civil Office under the Authority of the United States, which shall have been created, or the Emoluments whereof shall have been encreased during such time.")
} 
Our simple point is that Congress can evade many constitutional constraints if it can transfer the powers to regulate, to spend, and to lay taxes. In a sense, these constraints and others become default rules, where Congress need only worry about them if Congress is the one making the rules. If others are making laws, these constraints no longer apply and do not much matter.

Recognizing that many constitutional constraints might seem useless under the naïve view, Posner and Vermeule claim that the naïve view formally protects bicameralism and other constitutional values." After all, all statutes delegating lawmaking authority must themselves go through bicameralism and presentment and will necessarily be affected by these and other constitutional values. But the same could be said for delegations of the right to vote. If Congress delegates the de jure rights of legislators, Congress's delegation statute will reflect constitutional design in the same way. Such delegation statutes also will have to go through bicameralism and presentment. Just as important, such delegations will reflect the effects of the detailed selection process for federal legislators. Yet Posner and Vermeule reject the latter delegation as inconsistent with the Constitution while embracing the former. What seems true of one type of statutory transfer (delegation of lawmaking authority) would seem equally true for another (delegation of voting rights).

\section{Analogizing Legislative and Judicial Delegations}

The normative implausibility of the naïve view comes into clearer focus by considering an Article III analogue. Suppose that we find in Article III a nondelegation doctrine that prevents federal judges from delegating their votes on judgments in cases before them to persons who lack life tenure and salary protections, ${ }^{13}$ and who were not appointed as the Appointments Clause provides. ${ }^{14}$ That surely seems correct as a matter of constitutional law.

But suppose that an Article III court renders a final "judgment" in a case that the relevant legal rights and duties of the parties are whatever the President-or perhaps her agent, Sheila, the U.S. Marshall-determines those legal rights and duties to be. If accused of im-

\footnotetext{
1 See Posner and Vermeule, $69 \mathrm{U}$ Chi L Rev at 1749-51 (cited in note 2).

12 As we discuss below, we believe that granting non-members the right to vote is unauthorized and therefore forbidden because neither Congress nor individual members have such constitutional authority. But the same conclusion could be reached regarding the delegation of the power to make laws or rules. Though Posner and Vermeule think otherwise, they assume that Congress's power to create laws includes the power to allow others to create laws. This latter conclusion is hardly obvious.

13 See US Const Art III, $\$ 1$.

14 US Const Art II, \$2, cl 2.
} 
properly delegating the Article III judicial power to a non-Article III judge, our judges can cite to Posner and Vermeule and declare that they have exercised the judicial power in rendering their judgment. The President (or Sheila) is not exercising Article III judicial power but is instead only taking care to faithfully execute the judiciary's judgment. She has not been given a vote on a judgment and is not rendering a judgment of her own, and hence she is not acting as an Article III judge. Moreover, the values served by the detailed selection process and the tenure and salary protections for federal judges are formally served because all Article III judgments that transfer authority to the President are made by Article III judges who have salary protection and lifetime tenure, and who have been appointed under the process established in Article II. Surely, however, federal courts cannot so easily circumvent the safeguards of Article III by transferring their powers to the President. ${ }^{15}$

In conclusion, we find no good normative case for the naïve view. Rather, the normative case runs against Posner and Vermeule's view. Of course, as we said at the beginning of this Part, even a knockdown normative case against a doctrine does not mean that the doctrine is incorrect as a matter of constitutional law. The Founders may have been foolish, locking the back door against various dangers while leaving the front door wide open. That is possible. But in the absence of direct support in the text or in the legislative history, ${ }^{16}$ it is improbable.

Still, we have not demonstrated that the naïve view is wrong or that the conventional view is correct. What we have demonstrated is that the naïve delegation prohibition, which elevates form over substance, is rather pointless in the absence of the conventional nondelegation doctrine. And that is strong evidence that the naïve view is wrong.

15 Here's another analogy: Suppose the President negotiates a treaty with China that authorizes the President to make international law commitments through a document called the "P-treaty." Such P-treaties would have the force of law upon presidential signing and would not need Senate approval. Should the Senate ratify the initial treaty with China, one might conclude that any subsequent P-treaties would result from faithful presidential "execution" of the U.S.China Treaty. But we think it would be difficult to refute the notion that the President is in fact making treaties without following the specified constitutional process, and that he and the Senate are evading the Senate's treaty role. Calling presidential treaty-making "treaty execution" does not avoid the issue.

16 If, in the $1780 \mathrm{~s}$, there had been some notorious problem associated with assemblies granting others the right to vote but no corresponding difficulties with delegations of legislative power, then one might see why the Founders would adopt the former prohibition but not the latter. In these circumstances, a partial prohibition might have seemed sufficient. Yet Posner and Vermeule provide no evidence that one problem was more acute or prominent than the other, and hence, they do not explain why the Founders would have enacted a partial prohibition on third-party lawmaking. 


\section{What DiD The Founders MEAN BY "LegisLative PoWERS"? THE ORIGINALIST CRITIQUE}

Posner and Vermeule agree that Congress cannot delegate legislative power. ${ }^{17}$ The dispute concerns what constitutes an exercise of legislative power. Recall their claim that in the Constitution, the legislative powers consist of the right to vote on bills in Congress and other de jure powers of federal legislators. ${ }^{18}$ When a federal statute authorizes rulemaking outside of Congress, no matter how broad the delegation, the rulemaking institution never exercises legislative power when it makes rules. Instead, the rulemaking institution merely executes the law that authorizes its rulemaking. Posner and Vermeule maintain that institutions outside of Congress exercise legislative power only when they make rules without statutory (or constitutional) authorization." Hence, while authorized rulemakings are never exercises of legislative power, unauthorized rulemakings always usurp legislative power. ${ }^{20}$

Although they are unclear on this point, Posner and Vermeule also may believe that the Constitution establishes (or adopts) a certain nomenclature. They insist that "[c]reating rules pursuant to valid

17 Posner and Vermeule, $69 \mathrm{U}$ Chi L Rev at 1723 (cited in note 2) ("[W]e agree that the Constitution bars the "delegation of legislative power." ); id at 1729 ("The disagreement is not about whether the legislative power is vested exclusively in the Congress - both [the naive view and the conventional delegation metaphor] agree that it is.").

18 See id at 1726.

19 See id at 1725 ("[T]he president can be said to exercise legislative power only when creating binding legal rules without constitutional or statutory authority.").

20 We think that Posner and Vermeule are of the view that when the Constitution uses "legislative Powers" it references the de jure rights of federal legislators. But though they speak of "legislative power" at length, they nowhere provide a complete definition. It is possible that Posner and Vermeule have a two-part definition of "legislative power" - that the phrase includes both the de jure rights of legislators and the power to make rules for society.

If they hold this more complicated view, however, they run into serious difficulties. In this situation their position has to be that neither type of legislative power is delegable for its own peculiar reasons. The de jure rights of legislators are not delegable by statute because Congress lacks the power to transfer such rights. The power to make laws is not delegable by statute because it is a logical impossibility-presidential execution of a discretion-conferring statute can never be a delegation because the President by definition merely exercises the executive power.

But of course, as we point out later, their executive power claim, if true, must apply to all statutes, constitutional or not. Whenever the executive executes a statute, it is a simple, core exercise of executive power, and it cannot be the exercise of some other power. Thus, if a statute grants a member of the executive branch a vote in Congress, the statute cannot be said to delegate the legislative power because the statute merely calls for law execution, an exercise of executive power. This makes all talk of statutory delegations of legislative power silly because there cannot be such things.

On the other hand, if we are right that the exercise of executive power is irrelevant to the question of whether some other power is also being exercised or used, then delegations of legislative power are possible in both cases. If they then hold fast to their conclusion that one set of statutes is impermissible (delegations of voting rights) but other statutes are permissible (delegations of lawmaking power), they would then have to explain why some legislative powers are delegable and others are not. This they have not done. 
statutory authority isn't lawmaking." The statement strongly suggests that so far as the Constitution is concerned, the rules that noncongressional institutions make pursuant to statutory authority are not "laws." After all, if such rules were "laws," it would be hard to escape the conclusion that these non-congressional institutions engage in "lawmaking.",22

For originalists, the crucial issue is the original understanding of legislative power. Was the concept the broad one of lawmaking or rulemaking generally, in which case the conventional view of the nondelegation doctrine is likely correct? Or was the concept the naive one championed by Posner and Vermeule? Originalists also would ask what understanding of lawmaking and laws existed at the founding. By virtue of the Constitution, are rules created by other institutions in pursuance of statutory authorization never "laws" such that we would conclude that these institutions are not engaged in lawmaking?

In our view, at the founding, the legislative power was understood as the authority to make rules for the governance of society, whether or not exercised by a legislature. In the Constitution in particular, the legislative powers were those powers to make the laws, rules, and regulations listed in Article $\mathrm{I}$, Section 8. Our claim is that under the Constitution, it is possible to speak of someone else other than Congress exercising the legislative power because third parties might either usurp or receive a delegation of legislative power. Moreover, "lawmaking" may occur when someone, even outside the legislature, makes rules for the governance of society. Finally, "laws" are those rules that actually govern society whether made by a legislature, a despot, or an unelected judiciary.

\section{A. Rules and Regulations: Laws by Any Other Name}

We begin with the issues of whether the Constitution differentiates "rules" and "regulations" from "laws," and whether statutorily authorized rulemaking can ever be lawmaking. We do not believe that the Constitution distinguishes laws from rules, regulations, and the like. A general pronouncement creating, modifying, or rescinding legal obligations and rights is a law, regardless of who pronounces it and

21 Id at $1725-26$.

22 Nowhere in their article do the Professors actually distinguish "laws" from "rules" or "regulations." Yet because they do distinguish "lawmaking"-what Congress does-from law execution - what others do pursuant to statutory grants of delegated power - they may believe that only Congress enacts "laws." Others merely create rules while executing congressional laws. At other times, however, they seem to admit that what goes on in the regulatory agencies and in the courts is lawmaking. See id at 1732 (discussing how the Sherman Act and the Labor Management Relations Act have been held to authorize judicial "lawmaking" even though the cases they cite do not use this term). Thus they suggest that non-legislative institutions engage in lawmaking when they create rules outside of Congress. 
irrespective of whether the lawmaking is statutorily authorized or not. Underscoring the interchangeability of these terms, the Constitution refers to the products of lawmaking in a number of ways. Besides referring to Congress's power to make "laws,", the Constitution repeatedly speaks of Congress's power to make "rules" ${ }^{24}$ and "regulations."." Despite these differences in wording, no one thinks the Constitution describes different types of legislative authority by virtue of using different words. Indeed, even though the Faithful Execution Clause references "Laws" only, no one doubts that the President must take care to faithfully execute all "rules" of naturalization and must enforce all "rules" regulating the army and navy. Likewise, even though the Supremacy Clause refers to "Laws ... made in Pursuance" of the Constitution and not "rules and regulations" made in pursuance of the Constitution, ${ }^{27}$ no one doubts that "rules" concerning captures and "regulations" of state elections of federal legislators are part of the "supreme Law of the Land." Not surprisingly, contemporaneous usage from the founding reflects the interchangeability of the terms "laws," "rules," and "regulations."."

The interchangeability of these words suggests that when the executive writes a "rule" or "regulation" relating to captures pursuant to a federal statute that authorizes the executive to "adopt whatever rules relating to captures on the land and water" it sees fit, the execu-

23 See, for example, US Const Art I, $\$ 7, \mathrm{cl} 2$ (requiring that every bill be presented to the President prior to becoming a "Law"); US Const Art I, § 8, cl 18 (authorizing Congress to make necessary and proper "Laws").

24 See US Const Art I, $\$ 8$, cl 4 (Congress may create a "uniform Rule of Naturalization."); US Const Art I, $\S 8, \mathrm{cl} 11$ (Congress may establish "Rules concerning Captures."); US Const Art I, $\$ 8, \mathrm{cl} 14$ (Congress may provide "Rules for the Government and Regulation" of the army and navy.).

25 See US Const Art I, $\S 4$, cl 1 ("Congress may ... by Law make or alter ... Regulations" concerning the election of members of Congress.); US Const Art IV, $\S 3, \mathrm{cl} 2$ (Congress may create "Rules and Regulations respecting" United States territory and property.); US Const Art III, $\S 2$, cl 2 (Congress may make "Regulations" concerning the Supreme Court's appellate jurisdiction.).

26 US Const Art II, $\& 3$ ("[The President] shall take Care that the Laws be faithfully executed.").

27 US Const Art VI, cl 2 ("This Constitution, and the Laws of the United States which shall be made in Pursuance thereof ... shall be the supreme Law of the Land.").

28 We can conclude that these words were synonyms by virtue of the fact that the Founders referred to "laws" where the Constitution referred to "rules" and sometimes referred to "rules" or "regulations" where the Constitution referred to "laws." See, for example, Max Farrand, ed, 2 The Records of the Federal Convention of 1787271 (Yale rev ed 1937) (Charles Pinckney discussing state naturalization "laws"); Jonathan Elliot, 3 Debates in the Several State Conventions on the Adoption of the Federal Constitution 59 (2d ed 1836) (Patrick Henry noting that Congress may or may not make "regulations" to control tax collectors); id at 243 (George Nicholas noting that Congress will enact easy and convenient excise "regulations"); id at 439 (Edmund Pendleton declaring that Congress cannot use the Necessary and Proper Clause to enact a "regulation" that affects the larger interests of citizens); id at 480 (James Madison noting that Congress will make laws/regulations to redeem continental debt). 
tive engages in lawmaking; for the resulting rules and regulations are laws, just as they would be if Congress had itself enacted the capture rules. ${ }^{2 y}$ Yet to say that the President engages in lawmaking in this hypothetical does not answer the principal question about the meaning of legislative powers in Article I. If the "legislative Powers" referenced in the Article I Vesting Clause $e^{3)}$ are only the de jure rights of federal legislators, it might not matter if the President engages in lawmaking from time to time."

\section{B. Article I's Legislative Powers Belong to Congress, Not Legislators}

Posner and Vermeule's conception of legislative powers neither fits with the text nor coheres with the original understanding of legislative power. Consider the textual problems first. If the power to vote in Congress and the de jure powers of federal legislators comprise the legislative powers mentioned in Article I, the Vesting Clause is a rather odd bird. A paraphrase of it would read as follows: "All powers to vote in Congress and all related powers of legislators herein granted shall be vested in a Congress, comprised of two chambers." It is hard to know what to make of such a statement. Neither Congress nor its chambers can possibly enjoy the power to vote in Congress. Nor can Congress possibly enjoy the de jure powers of individual legislators. Will Congress decide how individual members ought to vote?

This rendition of the Vesting Clause poses particular problems for Posner and Vermeule. One of the reasons they conclude that Congress cannot delegate the right to vote in Congress is that individual legislators and not Congress possess legislative voting rights. ${ }^{32}$ But if Posner and Vermeule's definition of legislative powers is correct, Congress

29 As noted, we are unsure whether the concepts of "lawmaking" and "law" are central to Posner and Vermeule's claims. Nonetheless, it seems appropriate for us to discuss these matters lest someone expand upon the claims of Professors Posner and Vermeule by arguing that the Constitution somehow makes it clear that only Congress may make "laws" and that others institutions may enact different types of binding constraints called something else (perhaps "rules" or "regulations").

30 US Const Art I, $\$ 1$.

31 We say "might" because even if we are wrong about the meaning of "legislative power," there still remains the question of whether Congress itself exercises its power to regulate commerce when it authorizes others to regulate commerce. Nonetheless, we do not need to get into such questions because Posner and Vermeule clearly believe that "legislative power" cannot be delegated (presumably because the phrase is used in the Article I Vesting Clause). If we can show that the President exercises legislative power when he writes commerce rules pursuant to a statutory grant to "regulate commerce," we have done enough for purposes of this Article.

32 See Posner and Vermeule, $69 \mathrm{U}$ Chi L Rev at 1756 (cited in note 2) (claiming that Congress cannot delegate the power to vote on bills because "[t]he power to vote on bills is possessed by individual members of Congress, not by the Congress as such"). 
somehow does enjoy the power to vote in Congress. Congress is thus in a position to delegate these powers.

The more natural reading of "legislative Powers" is the conventional one: The legislative powers referenced in Article I are those powers listed in Article I, Section 8, such as the power to lay and collect taxes, ${ }^{3,}$ the power to regulate commerce, ${ }^{34}$ etc. ${ }^{35}$ These are the legislative powers "herein granted." So when Congress makes a law laying out uniform rules of bankruptcy, it exercises its legislative power over bankruptcy. ". Likewise, when Congress establishes postal roads and post offices, it exercises its legislative power over postal matters. ${ }^{37}$

If we (and the conventional wisdom) are right, the power to vote in Congress and the other de jure rights of legislators lie outside this more familiar conception of legislative power. In particular, such powers are not legislative powers within the meaning of the Vesting Clause. Instead, the power to vote on bills in Congress is the means by which individual members decide how Congress will exercise its legislative powers to make laws. In other words, under our Constitution, individual members of Congress do not have any "legislative powers"-only Congress does. For good reason, Senators and Representatives typically don't ask each other how they intend to exercise their individual "legislative powers" because they have none.

This highlights another odd feature of the naïve view of the legislative power. If Posner and Vermeule's definition is correct, it must be possible to have constitutions where absolutely no one enjoys any legislative powers. Imagine a constitution that does not create a conventional legislature but instead grants authority to an absolute monarch to regulate commerce, raise armies, declare war, and control all the other powers found in Article I, Section 8. Posner and Vermeule appear to be committed to the view that because no one can vote in a legislature, and no one can exercise the typical de jure powers of legislators-because there is no legislature - this hypothetical constitution does not vest any legislative powers. ${ }^{38}$ Indeed, the absolute monarch's

33 US Const Art $1, \$ 8, \mathrm{cl} 1$.

34 US Const Art I, \$ 8, $\mathrm{cl} 3$.

35 See generally US Const Art I, \& 8. It is also probable that the legislative powers referenced in the Vesting Clause included those lawmaking powers conferred upon Congress in other portions of the Constitution.

36 US Const Art I, $\$ 8, \mathrm{cl} 4$.

37 US Const Art I, $\$ 8, \mathrm{cl} 7$.

38 If they were to treat the absolute monarch in the above hypothetical as endowed with the legislative power, they would have to similarly regard the U.S. President as endowed with at least some legislative power when Congress passes a statute that allows the President to enact whatever rules (or laws) he deems appropriate over commerce, armies, etc. In other words, if a constitution grants the absolute monarch legislative power by granting him authority "to regulate commerce," a statute also grants legislative power if it likewise grants the President the power "to regulate commerce." 
lawmaking is constitutionally authorized, so under their theory there can be no exercise of legislative power.

Any theory of the meaning of legislative power that contemplates that legislative power does not exist in the absence of a typical legislature is problematic. One can have legislative power even in the absence of something resembling a conventional legislature or a legislative process. Indeed, the Founders spoke of every government having three powers: legislative, judicial, and executive. ${ }^{34}$ Because the Founders were familiar with absolute monarchies, their statements about the three powers of government only make sense if the absolute monarch were understood to have the legislative power (as well as the other two powers). Indeed, there are numerous statements from the founding era about despots who wielded both the executive and legislative powers.

Perhaps swayed by the intuitive appeal of the conventional meaning of legislative power, Posner and Vermeule at one point seem to adopt it. They assert that if the President (or some third party) wrote rules in the absence of constitutional or statutory authority, that would be an exercise of "legislative power." That conclusion must be wrong if their naïve definition of legislative power is right. After all, when the President creates unauthorized rules relating to commerce or patents, he does not vote in Congress, nor does he exercise any of the de jure powers held by individual federal legislators. To be faithful to their naïve definition of legislative power, they must believe that although the President may be doing something unauthorized, he is not exercising the legislative power. In abandoning the naïve view of legislative power when it comes to unauthorized executive lawmaking, they inexplicably adopt the conventional (and in our view correct) understanding of that power."

Under our view, something is (or is not) an exercise of legislative power whether or not the particular law or rule created was constitutionally or statutorily authorized. Likewise, something is (or is not) an exercise of legislative power whether or not the relevant law or rule

39 See, for example, John Adams, Thoughts on Government (Boston 1776), in Charles S. Hyneman and Donald S. Lutz, eds, 1 American Political Writing during the Founding Era, 17601805401,404 (Liberty 1983) (considering "whether all the powers of government, legislative, executive, and judicial, shall be left" in a representative assembly).

40 Posner and Vermeule, $69 \mathrm{U}$ Chi L Rev at 1725 (cited in note 2).

41 It is also worth pointing out that Posner and Vermeule conspicuously embraced the conventional meaning of legislative power in their entrenchment essay. See Eric A. Posner and Adrian Vermeule, Legislative Entrenchment: A Reappraisal, 111 Yale L J 1665, 1675 (2002) (pointing out that the Constitution vests in "Congress 'all legislative Powers herein granted,' and then proceeds to supply both a careful enumeration of those powers in Article I, Section 8 and a detailed set of restrictions on those powers in Article I, Section 9"). Although scholars are free to change their opinions (indeed, it suggests open-mindedness), we think they were right the first time about the meaning of "legislative Powers" in Article I. 
went through a conventional legislative process. Thus, the absolute monarch exercises the legislative power because such a despot makes the rules for society whether or not he can point to a law or constitution that authorizes his lawmaking. Likewise, under the Constitution something called "Congress" could have been vested with the legislative powers found in Article I, Section 8 even if "Congress" consisted of a single person who exercised authority by unilateral decree. Our more basic constitutional claim is that whenever Congress authorizes an institution to exercise exactly the same power that Congress has in the Constitution, say, "to regulate Commerce ... among the several States," subjects. In other words, when Congress transfers to some institution the exact same legislative power that it enjoyed, Congress has transferred a particular legislative power. ${ }^{43}$ And that is true whether the institution is the President, the courts, or private parties.

\section{The Original Understanding of Legislative Power}

Apart from the textual difficulties with the naïve definition of legislative power, there is substantial evidence that, at the founding, individuals generally held the conventional view of the legislative power. The legislative power was the power to enact rules for society, whether those rules were called statutes, rules, regulations, or something else. ${ }^{4}$ Plural legislatures often exercised legislative power, but despots could exercise legislative power as well, notwithstanding the lack of a separate legislature. Whoever made the laws had the legislative power.

Examinations of Locke, Montesquieu, and Blackstone reveal that each defined the legislative power as the power to make laws/rules for the governance of society and not as the power to vote on legislation.

42 US Const Art $1, \$ 8, \mathrm{cl} 3$.

43 Just to be clear, we do not believe that all rulemaking occurring outside of Congress necessarily amounts to an exercise of legislative power. To be sure, one might argue that because Congress always could have written a more specific statute using its legislative power, every statute delegates legislative power to third parties by not eliminating such discretion. We wouldn't go so far. Because the Founders clearly did not believe that all federal statutes delegated legislative power, we don't adopt the extreme view that every statute delegates legislative power merely because it delegates discretion that Congress itself could have exercised under Article $I$. We think that for the Founders, the legislative power was a matter of the degree/scope of the discretion.

44 At this point, we should note that the phrase "legislative power" was also used to refer to the entity that actually made the law. Thus, under the Constitution, Congress was the "legislative power." In the discussion that follows, we don't discuss this usage because it clearly does not fit with the Article I Vesting Clause. For obvious reasons "Congress"-meaning the entity with the legislative power-cannot be vested in Congress.

45 In a footnote, Posner and Vermeule quickly dismiss the relevance of these theorists, claiming that "banalities about the separation of powers are too general and abstract" to favor 
As noted, many trace the conventional nondelegation doctrine to Locke's claim that the legislative power could not be delegated. ${ }^{46}$ Posner and Vermeule stress Locke's statement that the legislative power can make laws but cannot "make Legislators," arguing that one makes legislators by granting third parties votes in the legislature (or by otherwise granting them the rights of legislators in legislatures). ${ }^{47}$ They claim that one does not "make Legislators" in a Lockean sense merely by allowing third parties to make rules outside the legislature on particular subjects. ${ }^{48}$

We think that in focusing on but one of Locke's many statements, Posner and Vermeule have misunderstood him. To begin with, Locke's definition of legislative power belies their belief that legislative power consists of the right to vote in a legislature. Locke defined legislative power as the "right to direct how the Force of the Commonwealth shall be imploy'd for preserving the Community and the Members of it.", In other words, the legislative power was the power to make laws or rules for society. Moreover, Locke used "legislator" not merely as a synonym for members of a plural legislature but also to encompass anyone who exercised the legislative power, in other words, anyone who made laws. ${ }^{\text {sn }}$ Finally, Locke spoke of the possibility that one person might exercise the legislative power, ${ }^{\text {s. }}$ making it clear that the legislative power is not the right to vote on laws or the other de jure rights of legislators in a legislature. After all, when the legislative power is vested in one man, there will be no "vote" as a condition to its exercise.

If the Constitution adopts Locke's definition of legislative power, and if the Constitution nowhere authorizes the Congress to transfer the legislative powers that the people of the United States vested in

either the naïve or conventional view. Posner and Vermeule, $69 \mathrm{U}$ Chi L Rev at $1730 \mathrm{n} 27$ (cited in note 2). But these discussions are not nearly as abstract and general as they believe. As we discuss below, a close examination of what these theorists wrote cuts against three principles of the naïve nondelegation doctrine: the definition of "legislative power," the definition of "legislators," and the definitions of "laws" and "lawmaking."

46 See note 1 and accompanying text.

47 Posner and Vermeule, $69 \mathrm{U}$ Chi L Rev at 1727-28 (cited in note 2).

48 Id.

49 Locke, Second Treatise $\$ 143$ at 364 (cited in note 1). Later in the same paragraph, Locke observes that in welt-ordered commonwealths the legislative power is put into an assembly with the power to make laws. Id. See also id $\S 88$ at $324-25$ (noting that the legislative power is the power to decide what is worthy of punishment and the actual punishment itself); id $\S 89$ at 325 (describing how man, entering into civil society, authorized the "legislative" to make laws for him).

50 Id $\S 135$ at 357 (noting that legislative power can be concentrated in one person-the "legislator").

51 Id $\$ 138$ at 361 (discussing circumstances when the legislative power is "in one Man, as in Absolute Monarchies"). See also id $\S 91$ at 326 (same); id $\$ 153$ at 369 (noting that legislative power could be in one person's hands). 
Congress, then the Constitution prohibits the wholesale transfer of lawmaking authority over subject matters vested in Congress. Hence, should Congress delegate its power to make bankruptcy laws to the President, Congress has impermissibly made a (single) legislator; and when the President subsequently makes bankruptcy laws, the President improperly exercises one of the Congress's legislative powers. One might say that, in Lockean terms, "We the People" never consented to non-congressional exercises of the legislative power.

Baron de Montesquieu's treatment of the legislative power is not different in material respects. Montesquieu defined the legislative power as the power that enacts "temporary or perpetual laws, and amends or abrogates those that have been already enacted." Similarly, the legislative power was not tied to a plural legislature but could be exercised by a single person." And, once again, "legislators" included those who made laws unilaterally. ${ }^{\text {s. }}$

Far more important than Montesquieu's sundry discussions of legislative power is his famous separation-of-powers maxim. His admonition to keep separate the three powers of government relied upon the conventional definition of legislative power. He claimed that when the executive and legislative powers are "united in the same person, ... there can be no liberty, because apprehensions may arise lest the same monarch or senate should enact tyrannical laws, to execute them in a tyrannical manner.","s5

If the exercise of legislative power required the existence of a separate legislature, it would have been impossible for Montesquieu to contemplate the consolidation of legislative and executive powers in one person's hands. Clearly, Montesquieu believed that the legislative power to make laws could be exercised by one person and outside the confines of a typical legislature. Moreover, one does not satisfy the concerns underlying Montesquieu's famous maxim when the same person exercises executive power and a general "rulemaking" power in pursuance of statutory grants. In this situation, there can be no liberty because one person can enact tyrannical rules (laws) and execute them tyrannically. When Montesquieu spoke of the same person exercising the legislative and executive powers, he confirmed that one exercises legislative power by making laws/rules, whether or not one

52 Montesquieu, The Spirit of the Laws 182 (D. Appleton 1900) (Thomas Nugent, trans).

53 See id (noting that liberty cannot exist where the executive and the legislative are combined "in the same person, or in the same body of magistrates"); id at 13 (referring to Solon, who unilaterally made laws in Athens, as a legislator); id at 217 (noting that Roman magistrates sent to conquered lands had all three powers and therefore were "despotic").

54 Id at 13.

55 Id at 182. 
makes them by adhering to something resembling legislative procedure in a legislature.

Later discussions confirm the claim that Montesquieu defined the legislative power as the power to make rules for society, whoever might exercise the legislative power, and however they might exercise it. "Were the executive power to determine the raising of public money otherwise than by giving its consent, liberty would be at an end, because it would become legislative in the most important point of legislation." ${ }^{, 56}$ Translated into the Constitution's language, were the President given the power to lay taxes, liberty would be at an end because the President would "become legislative in the most important" legislative area - control of the purse.

Not surprisingly, William Blackstone likewise defined the legislative power as the "power of making laws" and as the ability to "prescribe the rule of civil action." "Like his predecessors, Blackstone did not define it as the power to vote on laws in a legislature or as the power to exercise the de jure rights of members of an assembly. Indeed, though the king did not actually vote in parliament (he had what Blackstone called the power of "royal assent"), Blackstone nonetheless noted that the king was a branch of the legislative power. ${ }^{59}$ That statement would have been false had the legislative power consisted of the right to vote in parliament and other de jure rights of members.

More important than what Locke, Montesquieu, and Blackstone thought, the Founders themselves understood that legislative power was the power to make laws and not the power to vote in a legislative body. To begin with, whenever state constitutions discussed legislative power or authority," they used the phrase in the exact same way the Constitution does. Repeatedly "legislative power" was said to rest with a unicameral or bicameral institution. ${ }^{\text {.2 }}$ Once again, if the "legisla-

56 Id at 193.

57 William Blackstone, 1 Commentaries on the Laws of England $* 52$ (emphasis omitted). See also id at *146 (paraphrasing Montesquieu's maxim).

58 Id at *164; id at *150 ("The crown ... may approve or disapprove of the alterations suggested and consented to by the two houses.").

59 Id at *155 (defining the "constituent parts of a parliament" as the king, lords, and commons).

6) Interestingly enough, Blackstone claimed that members of the House of Lords could delegate their right to vote to other Lords. Id at *162 ("[E]very peer . . may make another lord of parliament his proxy, to vote for him in his absence."). Members of the House of Commons could not do this, however, because they represented the people rather than themselves. See id.

6t In the discussions that follow, we assume that in the 1780 s people used the phrases "legislative authority" and "legislative authorities" as synonyms for legislative power.

62 See, for example, NY Const of 1777 Art II, reprinted in William F. Swindler, ed, 7 Sources and Documents of United States Constitutions 172 (Oceana 1978) ("[T]he supreme legislative power within this State shall be vested in two separate and distinct bodies of men."); Pa Const of 1776, Plan or Frame of Government, $\$ 2$, reprinted in William F. Swindler, ed, 8 Sources and Documents of United States Constitutions 279 (Oceana 1978) ("[T]he supreme legislative power 
tive power" was the power to vote in a legislature or to exercise the de jure powers of legislators generally, it would have been odd for state constitution-makers to proclaim that the power to vote in the state assembly was granted to the state assembly and to have repeated this odd phrasing in state after state.

Political documents of the era confirmed that the legislative power was the power to enact laws and not the specific power to vote in legislatures. The Declaration of Independence complained that the King of England had refused to allow new legislatures to be elected after he dissolved them, "whereby the Legislative powers" returned to the people at large. ${ }^{63}$ For the Declaration to speak of legislative powers existing in the absence of legislatures indicates that its famous signatories did not believe that the legislative powers consisted of the rights of conventional legislators. ${ }^{4}$ The Declaration was clearly relying upon a Lockean understanding of legislative power-it was the power to make laws, and it reverted back to the people when their designated agents no longer could exercise it. In addition, the famous Essex Result, a seminal American tract on separation-of-powers principles, defined legislative power as that which "mak[es] laws, or prescrib[es] such rules of action to every individual in the state." The Result also cited Montesquieu for the proposition that the legislative and executive powers should be kept separate because no single institution should have the power to make and execute the laws.

An examination of the actual drafting and ratification of the Constitution confirms the conventional understanding of legislative power as the authority to enact laws and not the de jure powers of legislators acting in a legislature. The Records of the Philadelphia Convention are replete with the conventional usage that we would ascribe to the phrase "legislative powers." For instance, the Virginia Plan provided that the National Legislature would be able to "enjoy the Legis-

shall be vested in a house of representatives of the freemen of the commonwealth or state of Pennsylvania."); SC Const of 1778 Art II, reprinted in Swindler, ed, 8 Sources and Documents at 469 (vesting legislative power in "two distinct bodies").

63 United States Declaration of Independence (1776).

64 Essays prior to the Declaration of Independence defined the legislative power as the power to make laws. See, for example, Letter by T.Q., Boston Gazette \& Country J (Apr 18, 1763), reprinted in Hyneman and Lutz, eds, 1 American Political Writing 19, 20 (cited in note 39) (noting that "entrusting the same gentlemen with legislative and judiciary power, or the power of making laws and judging of them after they are made," had been criticized by Montesquieu); Demophilus, The Genuine Principles of the Ancient Saxon, or English Constitution, in Hyneman and Lutz, eds, 1 American Political Writing 340, 345 (cited in note 39) (noting that the Saxons had "legislative authority in every tithing, which made laws and regulations").

65 Theophilus Parsons, The Essex Result, in Hyneman and Lutz, eds, 1 American Political Writing 480, 492 (cited in note 39). The Essex Result also noted that the legislative power should not be united with the other powers of government in one person's hands, thus confirming that legislative power was not just the power to vote in a legislature. Id at 494-95. 
lative Rights vested in Congress by the Confederation \& moreover to legislate in all cases to which the separate States are incompetent, or in which the harmony of the United States may be interrupted by the exercise of individual Legislation." "When the delegates discussed this proposal, James Madison referred to both of these authorities as "legislative power." Neither he nor the Virginia Plan referenced the rights of legislators; they referenced the power to make laws, in one case the limited legislative authorities vested with the Continental Congress, and in the other case a sweeping legislative authority over all situations where individual state legislation would be incompetent. Similarly, James Wilson claimed that the powers of war and peace were generally considered to be "legislative powers" and hence should be exercised by Congress and not the President. ${ }^{\circ *} \mathrm{~A}$ statement by Gouverneur Morris provides particularly powerful evidence of the conventional view of legislative power. While discussing the failed Council of Revision, Morris noted that if we divided the three powers of government - the power to make, execute, and judge the lawsamongst three people, the executive and judicial would want some check on the lawmaker. ${ }^{69}$ Of course, if legislative power were not the power to make laws but were instead the power to exercise the de jure rights of legislators, then it would make no sense to speak of one person having all these rights in their entirety. As noted, when one person exercises the legislative power, there is no need for the right to vote on legislation.

As one might expect, the public ratification debates likewise equate legislative power not with the rights of legislators but with the power to make laws generally and with the powers granted to Congress in Article I, Section 8 in particular. Speaking in the Pennsylvania Convention, James Wilson denied that the Necessary and Proper Clause ${ }^{70}$ granted the Congress a "general legislative power." $\mathrm{He}$ also spoke of why annual legislative elections made sense in the states-

66 Max Farrand, ed, 1 The Records of the Federal Convention of 178721 (Yale rev ed 1937).

67 Id at 52-53 (notes of James Madison on proceedings).

68 Id at 73-74 (comments of James Wilson recorded in Pierce's notes).

69 Max Farrand, ed, 2 Records of the Federal Convention 78-79 (cited in note 28) (stating that the executive and judiciary ought "at least to have an opportunity of stating their objections agst. acts of encroachment" by the lawmaker). We should note that although Morris did not use the precise phrase "legislative power" it seems clear to us that he was referring to that power.

70 US Const Art I, $\$ 8$, cl 18 .

71 Jonathan Elliot. 2 The Debates in the Several State Conventions on the Adoption of the Federal Constitution 448-49 (2d ed 1836) ("I trust it is meant that [Congress] shall have the power of carrying into effect the laws which they shall make under the powers vested in them by this Constitution."). See also id at 461 (comments of Wilson that it made no sense to grant legislative power-the power to make laws-unless the government also had executive and judicial powers); id at 469 (same). 
they had "legislative power" "in all cases.", Because the Congress would not have such authority, annual elections were unnecessary. In the New York Convention, Alexander Hamilton noted that no one federal institution would have the legislative power; instead it was shared across three institutions - the Senate, the House, and the President. ${ }^{73}$ In Virginia, James Madison noted that the federal government would have "legislative powers on defined and limited objects." In the same convention, John Marshall noted that there could be no problem with extending federal "legislative power" across the country because legislating (making laws) was easy; executing the laws was difficult." Each of these uses of "legislative power" coheres with our claim that the legislative power was the power to make law; each fits poorly with the notion that legislative power references the rights of legislators.

The Federalist is quite clear about the meaning of legislative power. In Federalist 33, Alexander Hamilton asked the rhetorical question: "What is a LEGISLATIVE power, but a power of making LAWS? What are the means to execute a LEGISLATIVE power but LAWS? What is the power of laying and collecting taxes, but a legislative power, or a power of making laws, to lay and collect taxes?" Later, in Federalist 75, Hamilton observed, in the context of discussing treatymaking, that " $[t]$ he essence of the legislative authority is to enact laws, or, in other words to prescribe rules for the regulation of the society." In Federalist 83, Hamilton insisted that

the power of congress or in other words of the national legislature, shall extend to certain enumerated cases. This specification of particulars evidently excludes all pretension to a general legislative authority; because an affirmative grant of special powers would be absurd as well as useless, if a general authority was intended.

72 Id at 533 .

73 Id at 348 ("The legislative authority is lodged in three distinct branches, properly balanced.") (emphasis omitted).

74 Elliot, 3 The Debates in the Several State Conventions at 95 (cited in note 28) (noting that "the powers of the federal government are enumerated").

75 Id at 232 ("Extent of country may render it difficult to execute the laws, but not to legislate."). See also id at 558 (Marshall noting that just because Congress had "legislative power" over a future district did not mean that individuals would be afraid to work in the district); id at 443 (George Nicholas's comments that the judiciary could judge the extent of "legislative powers" including the taxing power and the Necessary and Proper Clause).

76 Federalist 33 (Hamilton), in Jacob E. Cooke, ed, The Federalist 203, 204-05 (Wesleyan 1961).

77 Federalist 75 (Hamilton), in Cooke, ed, The Federalist 503, 504 (cited in note 76).

78 Federalist 83 (Hamilton), in Cooke, ed, The Federalist 558, 560 (cited in note 76). 
And Madison, in Federalist 47, cited Montesquieu's maxim as support for keeping the legislative power - the power to make laws-separate from the executive power. He also noted that though the king had a share in legislative power in England, he could not make any law on his own. ${ }^{79}$ Once again, each of these uses of legislative power coheres with our claim that the legislative power is the power to make rules for society; none fits well with the naïve definition of legislative power.

Final bits of evidence from the early post-ratification period might prove illuminating: James Madison, writing as Helvidius, twice observed that the power to declare war was listed amongst the other "legislative powers," and that therefore the power to declare war was not an executive power but a legislative power. "Whatever the merits of Madison's taxonomy, he certainly regarded the "legislative powers" mentioned in the Article I Vesting Clause as referencing the legislative authorities granted in Article I, Section 8. Likewise, in his famous lectures on law, James Wilson observed that the legislative power was the power to make laws. ${ }^{81}$ He also spoke of a single person enjoying the legislative and executive powers, which meant that the person was both an "executive magistrate" and a "legislator." Once again, even though there would be no de jure rights of legislators in such a situation (because there would be no legislature), there still would be a legislator because someone would have the sole possession of the legislative power - the power to make laws.

\section{Simultaneous Exercises of Executive and Legislative Power}

We have laid out a detailed argument about the best original meaning of legislative power. At this point, Posner and Vermeule might respond that this is all beside the point. They might claim that whatever the meaning of legislative power, when the President executes a statute delegating discretion, he exercises executive power and not legislative power because he merely executes the statute. As they

79 Federalist 47 (Madison), in Cooke, ed, The Federalist 323, 326 (cited in note 76) ("The magistrate in whom the whole executive power resides cannot of himself make a law.").

80) James Madison, Letters of Helvidius No 1, in Phillip B. Kurland and Ralph Lerner, eds, 4 The Founders' Constitution 66, 67-68 (Chicago 1987) (noting that a declaration of war repeals peace-time laws and is therefore legislative); James Madison, Letters of Helvidius No 2, in Kurland and Lerner, eds, 4 The Founders' Constitution 69, 70 ("The power to judge of the causes of war, as involved in the power to declare war, is expressly vested, where all other legislative powers are vested, that is, in the congress of the United States.").

81 See, for example, Robert Green McCloskey, ed, 1 The Works of James Wilson 292 (Belknap 1967) ("[The legislative] power of government [] is intrusted with the making of the laws.").

82 Id at 298 ("In the character of executive magistrate, he receives all the power, which, in the character of legislator, he thinks proper to give."). 
put it, "[t]he power that executive agents wield pursuant to a statutory grant is simply executive power in the core sense" ${ }^{, k 3}$ because they are "simply executing the statute according to its terms." Almost as a matter of logic, they conclude that the President can never exercise legislative power when he executes a law because execution of a law is always and only an exercise of executive power.

We agree that presidential execution of a law is generally an ordinary exercise of his executive power. ${ }^{85}$ But we believe they have too quickly discarded (or overlooked) a possibility. Perhaps the President exercises legislative power (making laws) in the process of exercising the executive power (executing the delegating statute). In other words, it is possible that one act, such as writing rules or laws, might involve the exercise of two powers.

Analogies might prove useful. Take an obvious judicial power, such as the power to judge criminal trials. Suppose Congress passes a statute that directs the President to act as a judge in criminal trials. When the President actually conducts criminal trials, he might be "executing the law." But we also might conclude that the statute authorizes him to exercise the judicial power as well. Likewise, consider Article V, under which Congress may propose amendments to the Constitution. If Congress passes a statute authorizing the President to propose constitutional amendments to be sent to the states, when the President subsequently does so, one could argue that he merely executes the delegating statute. On the other hand, one could conclude that in proposing amendments to the states, the President exercises not only his executive power but also the power of proposing constitutional amendments, a power that is normally vested with Congress alone.

83 Posner and Vermeule, 69 U Chi L Rev at 1726 (cited in note 2).

84 Id at 1725.

85 Here it seems appropriate to note our agreement with Posner and Vermeule's claim that "the predicate for the unitary executive claim is precisely that the relevant delegates are exercising executive power rather than legislative power - in other words that any nondelegation challenge has already been rejected." Id at 1758 n 133, commenting in part on Steven G. Calabresi and Saikrishna B. Prakash, The President's Power to Execute the Laws, 104 Yale L J 541, 549 (1994). We agree that unitary executive proponents should be understood as saying that the President controls all law execution but that he cannot control governmental officers (executive or otherwise) when they exercise legislative or judicial power. The President is a Chief Executive and is not empowered to control either lawmaking or the pronouncement of judgments. See generally Saikrishna Prakash, The Essential Meaning of Executive Power, 2003 U Ill L Rev 701; Saikrishna Prakash, Note, Hail to the Chief Administrator: The Framers and the President's Administrative Powers, 102 Yale L J 991, 992 n 5 (1993) (noting that the President can control any discretion constitutionally delegated to a subordinate officer in the executive).

Of course, it also should be noted that one could be a proponent of the unitary executive theory without subscribing to the view that massive grants of discretion are unconstitutional delegations of legislative power. We suspect that Posner and Vermeule fall into this camp of unitary executive adherents. 
Posner and Vermeule never explain why two (or more) powers cannot be exercised simultaneously. We believe that the executive can walk and chew gum at the same time. Just because the President exercises the executive power does not mean that he does not also exercise other governmental powers through the same acts. Hence, it is irrelevant that the execution of a statute delegating a congressional power involves the exercise of executive power. When one objects to the delegation of legislative power, one need not deny that the President (or someone else) "executes" the delegatory statute. One can accept this and still sensibly complain about (or even discuss) the President's supposed exercise of legislative or some other power not constitutionally vested in the President.

At times, Posner and Vermeule correctly accept that the exercise of executive power does not necessarily preclude the exercise of legislative power. If the Congress delegated to the President the right to vote in Congress, that would be a delegation of legislative power, they claim. ${ }^{\text {*h }}$ But if presidential execution of a statute delegating discretion can never amount to an exercise of legislative power because law execution is only an exercise of core executive power, that would be true of presidential execution of a statute delegating votes in Congress. When the President executed the latter statute, it would also seem a core exercise of executive power. The statute might be unconstitutional, but presidential execution of it would also be an exercise of executive power in its core sense.

Nonetheless, despite the fact that the President would be executing the vote-delegating statute by voting in Congress, Posner and Vermeule conclude that the statute delegates to the President the legislative power. In other words, they conclude that simultaneous exercises of legislative and executive power are possible. Hence, they must be concluding that merely because something is an exercise of the executive power in the core sense does not mean that it cannot simultaneously be an exercise of legislative (or some other) power. If it is true that statutes that delegate the right to vote can simultaneously implicate both legislative and executive power, that conclusion also should be true of statutes that delegate great discretion. If the legislative power is the power to make laws, and if the power being delegated is the power to make laws, then the presence of law execution-an exercise of executive power-does not preclude the simultaneous exercise of legislative power.

86 See Posner and Vermeule, $69 \mathrm{U}$ Chi L Rev at 1726 (cited in note 2) ("A delegation of legislative power, in one universally recognized sense of that phrase, would arise if Congress or its individual members attempted to cede to anyone else the members' de jure powers as federal legislative officers, such as the power to vote on proposed statutes."). 
As we said earlier, exercises of legislative power do not depend upon the presence of a typical legislative process and a conventional legislature. At this point, we might add that exercises of legislative power do not depend upon the absence of exercises of executive or judicial power. Something is (or is not) an exercise of legislative power regardless of whether it is also the execution of a law or the rendering of a judgment.

We have suggested that throughout the eighteenth century the legislative power was the power to make the laws or rules of society. That is how Locke, Montesquieu, and Blackstone used the phrase. That is how the Framers and the Ratifiers used the phrase as they wrote and ratified the Constitution. Most importantly, we believe that is how the Constitution itself employs the term in the Article I Vesting Clause.

On the other hand, we believe that the alternative definition offered by Posner and Vermeule simply does not fit with the text or the history. If we substitute "de jure rights of legislators" in Article I, we have a clause that oddly proclaims that Congress has the rights of legislators. Moreover, there is very little historical evidence that legislative powers referenced the rights of legislators in a plural legislature. While we have sympathy for the notion that neither Congress nor individual legislators may delegate the rights of Senators or Representatives to those who are not members of Congress, that rule does not come from the negative implications of vesting the "legislative Powers" with Congress.

Accordingly, when the Constitution speaks of the "legislative Powers herein granted" it principally references Article I, Section 8. When someone makes laws or rules relating to "Commerce ... among the several States," commerce, whether or not the lawmaker acts through the typical legislative process and whether or not the lawmaker makes a law by executing another. Moreover, someone is a "legislator" in a Lockean sense if he or she makes laws, either as part of a collaborative (conventional) legislative process or by unilateral diktat.

\section{What Locke Meant By His Prohibition on LEGISLATIVE DELEGATIONS}

Whatever the meaning of legislative power in 1680 or $1787-1789$, and whether or not the Constitution itself prohibits delegations of leg-

\footnotetext{
87 Hence, we find sensible the notion that some judgments involve "legislating" from the bench, as when judges create law in the guise of interpreting it.

$8 \times$ US Const Art I, $\$ 1$.

89 US Const Art $\mathrm{l}, \$ 8, \mathrm{cl} 3$.
} 
islative power, there remains the important question of what John Locke meant by his famous delegation prohibition. Recall that Posner and Vermeule believe that Locke's prohibition means no more than that the legislative power cannot make additional legislators, and that one makes legislators only by granting third parties votes in the legislature. Thus, the legislature does not "make legislators" merely by allowing third parties to make rules outside the legislature.

Locke's many discussions of his nondelegation principle suggest the problem with reading Locke as if he were enunciating the naive nondelegation doctrine. Throughout his Second Treatise, Locke repeatedly insists that only the people can authorize someone else to make laws/rules for them. If someone not appointed by the people attempts to make binding rules, these rules are illegitimate because the people have not ceded to these individuals the power to make laws over them. Immediately before his famous nondelegation proviso, Locke claimed that when the people

have said, We will submit to rules, and be govern'd by Laws made by such Men, and in such Forms, no Body else can say other Men shall make Laws for them; nor can the people be bound by any Laws but such as are Enacted by those, whom they have Chosen, and Authorised to make Laws for them."

That was the predicate for Locke's famous claim that when the legislative power conveys the power to make rules/laws to a third party, the legislature transgresses the limits of its own authority. In this situation, the people are improperly asked to "submit to rules, and be governed by laws" made by legislators other than those the people had selected.

In his chapter on the "Dissolution of Government," Locke likewise makes clear that only those whom the people have appointed to exercise the legislative power can properly make laws/rules.

The Constitution of the Legislative is the first and fundamental Act of Society, whereby provision is made for the Continuation of their Union, under the Direction of Persons, and Bonds of Laws, made by persons authorized thereunto, by the Consent and Appointment of the People, without which no one Man, or number of Men, amongst them, can have Authority of making Laws, that shall be binding to the rest. When any one, or more, shall take upon them to make Laws, whom the People have not appointed so to do, they make Laws without Authority, which the People are not therefore bound to obey." 
Once again, unless appointed by the people, "no one Man, or number of Men" has the authority to make laws. Laws so made do not command the people's obedience.

Throughout these discussions, Locke is not playing some word game in which he distinguishes "Rules" from "Laws." He never claims that it is permissible for the legislative power to allow others to create "Rules" because these are not "Laws." Indeed, he uses these words interchangeably. ${ }^{12}$ For Locke, laws are not just the product of a legislative process but are more broadly the rules for society, however made. Had he adopted a naïve definition of "Laws" and "lawmaking" - only the legislative power can make laws and all others make rules, regulations, or something else - many of his comments would have made little sense. If, by definition, only the legislative power can make laws (and then only through a legislative process), it would have been impossible for him to speak of others making illegitimate "Laws." Indeed, he begins his chapter on legislative power limits with the following point:

This Legislative is not only the supream power of the Commonwealth, but sacred and unalterable in the hands where the Community have once placed it; nor can any Edict of any Body else, in what Form soever conceived, or by what Power soever backed, have the force and obligation of a Law, which has not its Sanction from that Legislative, which the publick has chosen and appointed. For without this the Law could not have that, which is absolutely necessary to its being a Law, the consent of the Society.

Accordingly, when someone makes edicts/rules/regulationslaws, if you will-without authority from the people, these putative laws are not binding because the institution seeks to exercise legislative power without the people's sanction. Likewise, when the legislature attempts to delegate lawmaking authority to a third party, the third party's rules are nullities because the third party was not chosen by the people to exercise the legislative power, and the people (according to Locke) never authorized a further delegation of legislative power to others. As Locke himself put it, when someone "introduces new Laws, not being thereunto authorized by the fundamental Ap-

92 Id $\$ 150$ at 368 (noting that Legislative has right to make "Laws" and "Rules" for society); id $\S 214$ at $408-09$ (same).

93 Id $\$ 134$ at 356 (emphasis altered). Clearly Locke uses "Sanction" here not to reference the power to transfer lawmaking, for he denies that legislators have this power. Instead, he means that edicts, rules, regulations, and laws do not have the force and obligation of a law unless the legislative power enacts the rules itself. Otherwise, these edicts and rules do not have the consent of "Society"-the People. 
pointment of the Society [by the people, that is], [the usurper] sets up a New Legislative" power.

In focusing on Locke's use of "legislators," Posner and Vermeule miss the bigger picture and adopt a cramped understanding of "legislator." Locke was enunciating a constraint on the legislative power's ability to transfer the power to make laws/rules; he was not directly enunciating constraints on the appointment of legislators. Moreover, as discussed earlier, he defined "legislators" not merely as those who vote in a legislature but as anyone (including a single person) who makes laws. Finally, Locke never mentioned voting in legislatures (or any of the de jure rights of legislators) at all when he discussed his nondelegation principle. Instead, he discussed the unauthorized nature of delegations of lawmaking (legislative) power.

None of this proves that the Constitution enshrines Locke's view about the limits on legislative power. Nonetheless, we think it important to respond to the revisionist reading of Locke offered by Posner and Vermeule. We believe that, so far as Locke is concerned, when the legislature allows the executive (or someone else) to make laws at his utter discretion, the legislature has made a single legislator, who in turn makes laws. And to have someone other than the popularly appointed legislative power make laws/rules was a complete anathema to Locke.

\section{SOME PROBLEMS WITH THE NAÏVE VIEW}

In this Part, we highlight some problems with the naïve nondelegation doctrine. In particular, we discuss the weak foundations of the naïve prohibition on the right to vote in legislatures, and we discuss whether broad delegations are likely in a world without a conventional nondelegation doctrine. In isolation, neither of these problems is dispositive. But when considered together with our discussion of the historical meaning of legislative power, these problems cast further doubt on the naïve view of delegation.

A. Why Not Likewise Inter the Naïve Prohibition on Delegations of the Right to Vote in Congress?

Although most of Posner and Vermeule's article aims to bury the conventional nondelegation doctrine, they also embrace a related, naïve prohibition: Neither Congress nor its members may confer upon others the right to vote in Congress. Although we agree that the Constitution is best read as incorporating these prohibitions, we think the logic of their arguments against the conventional nondelegation doc- 
trine likewise suggests that there is no naïve prohibition. If they are right about the conventional nondelegation doctrine, they would seem to be wrong in reading the Constitution as prohibiting grants of the right to vote.

At various points, Posner and Vermeule advance arguments in favor of their naïve prohibition. They contend that because the Constitution establishes a detailed process for selecting legislators and "carefully specifies" the resulting legislators, no one else can vote in Congress." Later, they claim that Congress cannot delegate the right to vote because Congress does not possess the right to vote in Congress; individual members do." They also seem to suggest that when the Constitution grants Congress the "legislative Powers," it bars others from exercising the same powers." Because they identify the de jure rights of legislators as the "legislative Powers" referenced in Article I, Section 1 , these are the powers that cannot be exercised by nonmembers.

We already have highlighted the problem with the claim that the prohibition against the delegation of congressional votes arises because of the carefully specified process for selecting legislators. That same argument applies with greater force to the making of laws: If we have a detailed process for selecting lawmakers and a detailed process for making laws, surely only members of Congress can make laws. Because they reject a far stronger negative implication arising out of the Constitution's lawmaking structure, we do not understand why they find their less-powerful process argument so compelling.

Their second argument, that Congress lacks the power to delegate the de jure rights of legislators, seems far more persuasive. Indeed, we agree that there is no authority for either Congress or members of Congress to delegate or convey the right to vote in Congress. Given our government of limited and enumerated powers, this means that neither Congress nor its members can confer congressional voting rights.

But we do not believe that Posner and Vermeule can simultaneously make this claim and yet retain their critique of the conventional nondelegation doctrine. With respect to the conventional nondelega-

95 See Posner and Vermeule, 69 U Chi L Rev at 1726 (cited in note 2).

\% Id at 1756.

97 Id at 1726. At two points, Posner and Vermeule seem to rely upon the Article I Vesting Clause. See id at 1729 (arguing that the Vesting Clause does not speak to whether a delegation of broad discretion is a delegation of legislative power); id at 1755 (denying that laws delegating discretion to the executive can ever be delegations of legislative power in a "constitutional sense").

98 We do not believe that the Necessary and Proper Clause permits Congress to enact such statutes, and we would argue that there is no other authority to confer congressional voting rights. 
tion doctrine, they insist that the nondelegation question arises only when Congress passes discretionary grants in pursuance of its enumerated constitutional powers. They argue that because Congress clearly has the power to grant discretion, there must be an affirmative (and implicit) prohibition against grants of excessive discretion if such grants are to be deemed unconstitutional. Statutory grants of authority are not delegations at all but are instead authorizations to exercise the executive power in particular ways, or so they claim."

Yet the same could be said of the right to vote in Congress. If the Necessary and Proper Clause plus the other enumerated powers authorize the granting of tremendous statutory discretion (including wholesale transfers of powers granted to Congress, such as the power to levy taxes), the Clauses likewise would seem to authorize the granting of congressional voting rights. If one "regulates commerce" by authorizing someone else to regulate commerce, one might equally claim that one "regulates commerce" by authorizing someone else to vote on commercial laws to be made in Congress.

Moreover, if the statutory delegation of the power to write commercial rules is not a "delegation" at all but rather an exercise of legislative power to be followed by an exercise of executive power (in the writing of the rules), the same must be said of the statutory delegation of the power to vote. To use their language, it should be equally "irrelevant" that there is no express enumerated power to "delegate" legislative voting rights because when Congress grants legislative voting rights to, say, the President, it "delegates" nothing. "It merely calls upon him to "execute" the statute granting voting rights.

Even if they could maintain their claim that Congress cannot delegate the "legislative Powers" - notwithstanding that Congress is

99 See id at 1728.

100 Posner and Vermeule might believe that delegation of the right to make laws is "proper" although the delegation of the right to vote is "improper." But that would take them down a Necessary and Proper path that they conspicuously eschew. See id at 1728 n 20.

101 See id at 1726.

112 In truth, to say that Congress "delegates" nothing in either circumstance is beside the point. The question ought to be whether Congress exercises its Article 1, Section 8 legislative powers either when it authorizes the President to make laws or when it authorizes him to vote in Congress. Posner and Vermeule quickly conclude that Congress may do the former. But that is precisely the dispute. Proponents of the conventional nondelegation doctrine vigorously deny that Congress may authorize someone else to make laws or rules regulating commerce. They claim that the Commerce and Necessary and Proper Clauses don't cede such authority. Given this forthright denial, it hardly suffices to accept as given that any statute delegating discretion "fall[s] within Congress's enumerated constitutional powers." Id at 1728. In making this claim, Posner and Vermeule assume the very point in question.

103 As noted earlier, we reject the claim that merely because the President exercises his executive power in executing a statute, he cannot also be exercising some other power (legislative, judicial, etc.). Nonetheless, if they are right, Congress "delegates" nothing when it conveys the right to vote; it merely creates the predicate (a statute) for the exercise of executive power. 
granted them by virtue of Article I-they would still have to explain why individual members cannot delegate their individual powers. After all, their claim is that individual members (and not Congress) possess the de jure rights of legislators. As they recognize, the only reason for the prohibition is the procedural one identified early on in their article. ${ }^{1 / 4}$ Given their reluctance to countenance implicit restrictions ${ }^{105}$ when there are express restrictions in Article I, Section 9 and elsewhere,${ }^{1 \text { 16h }}$ the naïve prohibition has little to support it (at least on their view). They certainly have not met the "heavy" burden they would impose before recognizing implicit constraints on federal power.

Finally, to the extent that they draw negative implications from the vesting of legislative powers in Congress, we think we have shown that the Vesting Clause refers to those powers found in Article I, Section 8 and not the de jure rights of legislators. Accordingly, any negative implications from the Vesting Clause actually support the conventional nondelegation doctrine and do not support the naïve prohibition.

The naïve prohibition's weak historical grounding also bears noting. Posner and Vermeule argue that there is little historical evidence in favor of the conventional nondelegation doctrine. According to them, Locke's epigram does not unequivocally support the conventional view, and there really is no other pre-ratification evidence supporting the notion that delegations of excessive discretion might have been considered unconstitutional. Like them, we have not systematically canvassed the sources to determine whether, at the founding, it was understood that legislatures that delegated excessive discretion in statutes were thereby unconstitutionally delegating legislative power. ${ }^{107}$ All we have done is attempted to demonstrate that the legislative power was the power to make rules/laws for society, not that the grant of such power to third parties was necessarily unconstitutional.

If, however, they believe that there is insufficient historical evidence in favor of the sophisticated view, they must think that even more true of the naïve prohibition. All of their historical evidence in favor of the notion that neither Congress nor its members can grant others a vote in Congress comes from a reinterpretation of a single statement (Locke's) that has usually been thought (rightly in our

104 See id at 1756.

105 They claim that the reluctance to recognize implicit constraints on Congress (and its members) "precludes justifying" restrictions based on "ambiguous inferences from text and structure, [and] by reference to isolated snippets of originalist material." Id at 1729.

106 See US Const Art $1, \$ 6, \mathrm{cl} 2$ (restricting members of Congress from concurrently holding other federal offices).

107 See Posner and Vermeule, 69 U Chi L Rev at 1732 (cited in note 2) ("We aren't aware of any comprehensive professional treatment of the history of the nondelegation doctrine, so ... our discussion here should be taken as tentative and revisable."). 
view) to support the conventional view. They cite no other historical evidence from political philosophers, from the founding era, or from the republic's early years that supports their naive prohibition. At least the conventional view has a few more scraps of evidence in its favor.

We say all this not to suggest that the naive prohibition is wrong. We believe that the Constitution contains both the naïve and sophisticated prohibitions. Rather, we make these points to suggest that, in disparaging the conventional nondelegation doctrine, Posner and Vermeule prove far too much. If one applied the same withering criticism to the naïve prohibition that they apply to the conventional prohibition, the naïve prohibition would be the weaker of the two. Merely noting that there is a specified process for selecting legislators should not be enough to establish the naïve prohibition, if, as they claim, two well-defined processes-one for lawmaking and one for selecting the lawmakers-are not enough to establish the conventional view. ${ }^{\text {trd }}$

\section{B. Predictions about a World without the Conventional \\ Nondelegation Doctrine}

Posner and Vermeule downplay the possibility of grand delegations. We probably will never see the Congress confer upon the President the power to rule by decree, as the German Reichstag did in 1933. Accordingly, they claim that we ought not twist and turn the Constitution to "discover" legal prohibitions that deal with improbable situations.

But one important reason why Congress might not have passed such grand delegations in the past is that Congress never understood that it had such authority. Congress's past restraint in the face of perceived limits on its power to delegate is no indication of how it would act under the Constitution described by Posner and Vermeule. Our constitutional past is a poor predictor of a future in which Congress is liberated from the conventional nondelegation doctrine.

Posner and Vermeule also point out that Congress is the institutional rival of the President and will not want to confer enormous discretion upon him. Yet in an era of party politics, this is not always so. Suppose one party controls both Congress and the presidency and a midterm election will transfer control of one (or both) chamber(s) to the other party. In this situation (which is not all that uncommon), a lame duck legislature has every incentive to pass grand delegations to the President. The lame duck Congress might enact statutes authorizing the President to spend money as he sees fit. Or the Congress may

108 See US Const Art I, $\$ 7, \mathrm{cl} 2$ (establishing the procedure for making laws). 
delegate to the President the power to lay taxes as he deems appropriate. Or the Congress might allow him to rule by decree, leaving nothing for the incoming Congress to do. And if this partisan Congress is smart, it will provide that its delegation ceases when the favored political party regains control of one (or both) chamber(s). History is replete with "midnight" acts passed by a lame-duck Congress, and so we do not regard these examples as far-fetched in the least. ${ }^{1(k)}$

\section{CONCLUSION}

We have not sought to prove that the conventional nondelegation doctrine is the one enshrined in the Constitution. Instead, we have merely supplied some reasons for doubting the normative value of the naive nondelegation theory that Professors Posner and Vermeule find in the Constitution. Their naïve theory posits a prohibition against delegating the de jure rights of legislators to third parties. We have suggested that this prohibition accomplishes very little if Congress can delegate its substantive powers. There is little point in prohibiting the delegation of a single vote to the Commander-in-Chief if you may cede him wholesale authority to raise armies and navies," to discipline members of the armed forces," and to fund them."

Additionally, we have sought to demonstrate that when the Constitution references legislative powers in the Article I Vesting Clause, it refers to the powers listed in Article I, Section 8 and not the de jure powers of legislators. From the time of Locke's Second Treatise at least until after the founding, the phrase "legislative power" consistently meant the power to make rules for society. Article I, Section 1's reference to "legislative Powers" was not a shorthand reference to the de jure powers of legislators. Instead, it principally referred to those powers listed in Article I, Section 8.

109 In a previous article, Professors Posner and Vermeule maintained that it is constitutional for one Congress to bind the legislative power of another. Posner and Vermeule, 111 Yale L J at 1666 (cited in note 41). For instance, their argument suggests that it is possible for one Congress to regulate commerce by denying future Congresses the authority to regulate commerce. They claim that a subsequent Congress could not repeal a well-drafted entrenching statute. Id at 1669. If both articles offer a correct view of the Constitution, it is possible for Congress to prohibit future congressional legislation entirely by delegating the power to make laws to some third party. Congress could transfer authority to the President to make laws laying taxes, regulating commerce, etc., and also provide that the delegation was irrevocable. It is hard to believe that the Constitution authorizes Congress to irrevocably delegate all its lawmaking power. It would mean that Congress not only has the power to depart from the initial allocation of power specified in the Constitution (Congress shall have these powers rather than someone else), but that Congress may permanently emasculate the default rule of congressional control of the legislative powers. We think this is unlikely.

110 US Const Art I, $\$ 8, \mathrm{cl} 12-13$.

111 US Const Art I, $\$ 8, \mathrm{cl} 14$.

112 US Const Art I, $\$ 8$, cl 1, 12-13. 
Third, we have sought to shore up the conventional reading of Locke's nondelegation maxim by suggesting that Locke opposed unauthorized law- or rulemaking, that is, lawmaking by an institution not authorized by the people to engage in such lawmaking. He was not merely opposing the power to convey votes in a legislature.

Finally, we have sought to highlight some of the problems with the naivve prohibition specifically and with the naïve nondelegation doctrine more generally. If Posner and Vermeule's unyielding criticisms of the conventional nondelegation doctrine are on the mark, the naïve prohibition must fall as well. Rather than interring one delegation prohibition and giving birth to another, their arguments suggest that they should have stuck to funerals and eschewed midwifery.

If Posner and Vermeule are right that the Constitution prohibits the delegation of legislative power, then their conclusion about the conventional nondelegation doctrine is wrong. On the other hand, they might be correct in concluding that the Constitution permits Congress to enact wholesale delegations of its power to "regulate Commerce," but that would be so only if they are wrong in concluding that the Constitution prohibits delegations of legislative power. Accordingly, even if one agreed with everything we have said, what remains to be answered is the important question of whether the Constitution actually authorizes the delegation of Congress's legislative powers. 


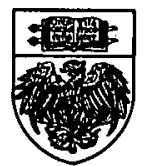

